\title{
STRATEGI KOMUNIKASI PEMBENTUKAN BUDAYA ORGANISASI BAITUL ARQAM SEBAGAI SARANA PEMBENTUKAN BUDAYA ORGANISASI ALA KH AHMAD DAHLAN DI AMAL USAHA MUHAMMADIYAH YOGYAKARTA (Studi Kasus Universitas Ahmad Dahlan Yogyakarta)
}

\author{
Oleh: \\ Dani Fadillah \\ Ilmu Komunikasi Universitas Ahmad Dahlan \\ e-mail : danifadillah@uad.ac.id \\ Twitter : @dn_fadillah
}

\begin{abstract}
Abstrak: Budaya organisasi merupakan sebuah identitas yang dapat membedakan organisasi satu dengan organisasi yang lain. Salah satu strategi komunikasi dalam rangka membuat budaya organisasi adalah dengan memberikan semboyan pada organisasi. Budaya organiasi tidak mengacu pada hal-hal seperti suku, etnis atau latar belakang seseorang namun budaya organiasi adalah cara hidup dari organisasi dan budaya organisasi bukan sekadar sebuah potongan puzzle melainkan puzzle itu sendiri. Dalam pandangan kita, budaya bukan sesuatu yang dimiliki organisasi; budaya adalah organisasi itu (Pacanowsky dan Trijulo dalam Morisan, 2009: 101),

Geertz (Morisan, 2009: 101) menulis bahwa "Manusia adalah hewan yang tergantung pada jaring-jaring yang telah dipintalnya sendiri." Jaring-jaring itu adalah budaya. Untuk menjelajahi jaring itu hingga ke pusatnya, orang luar harus mengetahui interpretasi yang bisa menyatukan jaring-jaring itu. Budaya adalah makna, pengertian, dan perasaan yang dibagi bersama Begitu pula Pacanowsky mengatakan bahwa budaya terdiri atas jaringan-jaringan makna yang dipintal orang. Pemintalan jaringan itu meliputi aktivitas memintal, maka kita tidak hanya memperhatikan struktur jaring-jaring budaya, tetapi kita juga harus memperhatikan proses pemintalan jaring-jaring itu. Proses itulah yang dinamakan komunikasi, dan komunikasi menciptakan realitas taken-for-granted (yang diambil dan diberikan di dunia kita).

Ada pun Universitas Ahmad Dahlan adalah sebuah institusi pendidikan tinggi dengan status sebagai Amal Usaha Muhammadiyah (AUM) memiliki budaya organisasi yang harus diinternalisasikan pada seluruh jajaran sumber daya manusia yang ada di dalamnya dari berbagai tingkatan dan status pekerjaan (dosen dan karyawan) agar sejalan dengan $\mathrm{MKCH}$ (Mukodimah Keyakinan Cita-Cita Hidup Muhammadiyah) yang diajarkan oleh KHA Dahlan. Disini peran elemen yang ada di dalamnya sangat diperlukan untuk proses internalisasi budaya tersebut.
\end{abstract}

Kata Kunci: Komunikasi, Budaya Organisasi, Universitas Ahmad Dahlan

\section{Pendahuluan}

Keberhasilan suatu organisasi ditentukan oleh adanya beberapa faktor, baik faktor internal maupun eksternal. Salah satu faktor internal yang turut menentukan keberhasilan organisasi itu adalah budaya organisasi. Budaya organisasi merupakan seperangkat nilai yang menjadi pedoman bagaimana seseorang bersikap dalam organisasi. Budaya organisasi akan 
memberi arah pada aktivitas organisasi. Budaya organisasi bisa dipengaruhi oleh budaya masyarakat sekitar, pimpinan puncak/gagasan awal pendiri organisasi, dan juga dari karyawannya sendiri. Budaya organisasi mempunyai peran yang sangat penting dalam suatu organisasi karena budaya organisasi terbukti dapat melakukan sejumlah fungsi, seperti menciptakan perbedaan dengan organisasi lain, menciptakan identitas organisasi, dan memudahkan terciptanya komitmen yang luas terhadap kepentingan bersama. Menurut Duncan dalam Kasali (1994:109), tujuan budaya adalah melengkapi para anggota organisasi dengan identitas organisasi dan menimbulkan komitmen terhadap nilai-nilai yang dianut organisasi.

Sebuah budaya organisasi yang kuat akan mendukung tercapainya tujuan organisasi dalam bidang produktivitas, pelayanan konsumen, dan kepuasan karyawan yang merupakan asset perusahaan yang penting. Budaya organisasi dapat memberikan standar yang tepat untuk apa yang harus dilakukan oleh karyawan. Dalam hal ini budaya organisasi berfungsi membentuk sikap dan perilaku karyawan. Karyawan perlu memahami dan mengerti budaya organisasi tempat mereka bekerja karena hal itu akan memberi efek yang kuat dalam keseharian mereka sebagai seorang karyawan.

Agar budaya organisasi dapat benar-benar dapat menjadi pedoman karyawan dalam beraktivitas sehingga tercipta identitas perusahaan yang akhirnya mendukung kemajuan organisasi, maka budaya organisasi perlu diatur dan dikomunikasikan pada karyawan. Untuk memperkenalkan budaya organisasi, ada beberapa cara yang biasanya diberikan oleh organisasi tersebut kepada karyawannya melalui kegiatan yang membangun rasa kekeluargaan, misalnya dengan memberikan program pelatihan bagi karyawan (Rachmadi, 1992:15). Pada perusahaan atau organisasi yang tidak mempunyai program khusus untuk melaksanakan internalisasi budaya organisasinya, maka karyawan tidak akan melihat budaya organisasi dengan jelas. Mereka hanya dikenalkan dengan lingkungan organisasi dan tujuan organisasi tanpa diberi pedoman bagaimana mereka harus bersikap dan berinteraksi.

Karyawan harus mempelajari budaya organisasi dengan cara bersosialisasi dengan budaya organisasi yang ada. Dengan melakukan sosialisasi, diharapkan agar karyawan mengenal semua komponen budaya organisasi, seperti nilai-nilai yang diterapkan dalam organisasi, lingkungan bisnis, sosok yang harus diteladani dalam organisasi, peraturanperaturan yang berlaku dalam organisasi, event-event yang sering diadakan organisasi baik secara formal maupun informal, jaringan komunikasi yang ada di dalam organisasi, apa yang boleh dan tidak boleh dilakukan oleh karyawan, dan lain sebagainya, sehingga timbul sikap keterlibatan (commitment) para karyawan kepada tujuan organisasi, dan dapat menanamkan 
nilai-nilai yang terkandung dalam budaya organisasi tersebut ke dalam diri meraka. Hal inilah yang disebut dengan internalisasi. Internalisasi budaya organisasi merupakan hal yang sangat penting, yang tidak boleh diremehkan. Dalam proses internalisasi, karyawan tidak hanya menerima budaya organisasi begitu saja, tetapi pasti akan mendiskusikannya dengan karyawan lain. Komunikasi memudahkan karyawan untuk memperoleh informasi yang menunjukkan apa yang harus dikerjakan di organisasi tersebut. Komunikasi dalam organisasi tidak semuanya tercipta secara formal, dimana ada batasan dan pengaruh dari garis hirarki dan birokrasi. Karyawan perlu berkomunikasi dengan nyaman dan bebas dalam mengurai informasi. Dalam hal ini, informasi informal mampu menjembatani kesenjangan hirarki dan birokrasi antar karyawan.

Keakraban pada setiap karyawan dapat membuat meraka nyaman dengan lingkungan kerja sehingga dapat membantu menyelesaikan tugas-tugasnya, serta mempermudah mereka melaksanakan internalisasi budaya organisasi. Kegiatan komunikasi tersebut dilakukan melalui kegiatan Public Relations. Public Relations merupakan upaya sungguh-sungguh, terencana, dan berkesinambungan untuk menciptakan dan membina saling pengertian antara organisasi dengan publiknya (Rachmadi, 1992:15).

Proses teknis dan administratif internalisasi budaya organisasi meliputi beberapa langkah. Pertama, menyediakan dan menyelenggarakan pelatihan yang ekstensif. Kedua, memasukkan penasehat untuk membantu manajemen dalam memastikan pesan secara tepat. Ketiga, secara berkala mengkomunikasikan informasi dari manajemen tingkat atas sampai kepada semua karyawan. Keempat, dibentuk dewan pengawas yang bertugas meninjau aktivitas organisasi.

Dengan banyaknya Perguruan Tinggu yang ada di wilayah Yogyakarta, Universitas Ahmad Dahlan sebagai salah satu instansi pendidikan tinggi terkemuka di wilayah Yogyakarta, yang telah memperoleh sertifikat SNI ISO / IEC 17025:2008. Dan untuk mempertahankan serta meningkatkan kepercayaan masyarakat, seperti yang telah ditetapkan sebagai kebijakan mutunya,Universitas Ahmad Dahlan menjadika Moral and Intelectual Integrity sebagai slogan yang menjadi penyemangat seluruh sumber daya yang dimilikinya.

Selain itu Universitas Ahmad Dahlan juga memiliki budaya perusahaan yang diciptakan sebagai identitas yang membedakan dengan instansi pendidikan tinggi lain, seperti peraturan-peraturan bagi karyawan yang mengadopsi 2 peraturan, yaitu standar dari pemerintah dan dari organisasi/amal usaha, yang di dalamnya terdapat penanaman akhlakul kharimah (misal : ada pembiasaan berinfaq yang diambil dari gaji karyawan; pengajian rutin untuk mahasiwa, dosen dan karyawan), dan event-event yang rutin dilaksanakan, seperti 
bimbingan membaca Al Quran secara klasikal wajib bagi karyawan umum yang diadakan secara terjadwal, pengajian mingguan per unit kerja, bahkan event yang tidak hanya melibatkan karyawan, namun juga masyarakat secara luas pada hari-hari besar dan pada saat peringatan milad Universitas Ahmad Dahlan Yogyakarta pada tiap tahunnya, yang terdiri dari berbagai agenda yang melibatkan partisipasi masyarakat luas seperti.

Peraturan organisasi yang di dalamnya terdapat budaya organisasi di Universitas Ahmad Dahlan Yogyakarta selalu mengalami perbaikan berdasar kritik dan saran dari para konsumen maupun dari karyawannya demi keberhasilan organisasi baik secara internal maupun eksternal. Universitas Ahmad Dahlan telah menetapkan dan memberlakukan peraturan baru. Awalnya Universitas Ahmad Dahlan menggunakan peraturan yang dibuat oleh internal organisasi/perusahaan, namun seiring dengan perkembangan, maka peraturan dibuat sesuai dengan standar dari pemerintah melalui kementrian terkait.

Perubahan peraturan tersebut telah berjalan secara rapi dan terukur. Oleh karena itu, penting bagi seluruh karyawan, dari tingkat paling bawah sampai tingkat teratas, untuk melakukan internalisasi budaya organisasi di Universitas Ahmad Dahlan agar mereka mengerti dan memahami apa yang menjadi hak dan kewajibannya dalam bekerja, dan mereka dapat melaksanakannya dengan sungguh-sungguh sehingga tujuan instansi/organisasi ini dapat tercapai maksimal, serta dapat mempertahankan ISO yang telah di dapat.

\section{Budaya Organisasi}

Budaya organisasi menurut Phithi Sithi Amnuai adalah seperangkat asumsi dasar dan keyakinan yang dianut oleh anggotaanggota organisasi, kemudian dikembangkan dan diwariskan guna mengatasi masalah-masalah adaptasi eksternal dan masalah internal (Taliziduhu, 1997:102).

Sedangkan menurut Peter F. Druicker dalam buku Robert G. Owen, Organizational Behavior in Education, budaya organisasi adalah pokok penyelesaian masalah-masalah eksternal dan internal yang pelaksanaannya dilakukan secara konsisten oleh suatu kelompok yang kemudian mewariskan kepada anggota-anggota baru sebagai cara yang tepat untuk memahami, memikirkan, dan merasakan terhadap masalah-masalah terkait. (Tika, 2005:4).

Budaya organisasi merupakan kristalisasi filosofi yang dianut suatu korporasi atau organisasi. Filosofi tersebut, oleh para pendiri dirumuskan menjadi nilai-nilai yang menjelaskan keberadaan organisasi secara social di tengah masyarakat. Nilai-nilai itu menyemangati, mengarahkan, dan menggerakkan setiap karyawan atau anggota organisasi untuk membantu organisasi mencapai tujuan. Budaya organisasi merupakan system nilai yang mengandung cita-cita organisasi sebagai sistem internal dan sistem eksternal sosial. 
Untuk mencapai cita-cita yang dikehendaki, maka tiap karyawan perlu mengoptimalkan sumber dayanya. Kegiatan di dalam organisasi tidak lagi dijalankan semata-mata hanya sebagai kegiatan rutin, tetapi dijalankan berdasarkan keyakinan bahwa itulah yang terbaik untuk mencapai tujuan organisasi.

\section{Unsur-unsur Budaya Organisasi}

Budaya organisasi tidak terbentuk begitu saja, tetapi ada beberapa unsur yang membentuknya. Dalam Farihanto (2013), Deal \& Kennedy (1991:4) membagi lima unsur budaya tersebut sebagai berikut :

a. Lingkungan usaha

Kelangsungan hidup organisasi (perusahaan) ditentukan oleh kemampuan organisasi dalam memberi tanggapan yang tepat terhadap peluang dan tantangan lingkungan.lingkungan usaha merupakan unsur yang menentukan terhadap apa yang harus dilakukan organisasi/perusahaan agar bisa berhasil.lingkungan usaha yang berpengaruh antara lain meliputi produk yang dihasilkan, pesaing, pelanggan, teknologi, pemasok, kebijakan pemerintah, dan lain-lain.

b. Nilai-nilai

Nilai-nilai adalah keyakinan dasar yang dianut oleh sebuah organisasi. Setiap organisasi/perusahaan mempunyai nilai-nilai inti sebagai pedoman berpikir dan bertindak bagi semua waganya dalam mencapai tujuan/misi organisasi. Nilainilai inti tersebut dapat berupa slogan atau motto yang berfungsi sebagai jati diri maupun harapan konsumen.

c. Pahlawan/panutan

Pahlawan/panutan adalah tokoh yang dipandang berhasil mewujudkan nilainilai budaya dalam kehidupan nyata. Panutan bisa berasal dari pendiri organisasi/perusahaan, manajer, kelompok organisasi atau perorangan yang berhasikl menciptakan nilai-nilai organisasi. mereka bisa menumbuhkan idealisme, semangat, dan tempat mencari petunjuk bila terjadi kesulitan/masalah dalam organisasi.

d. Ritus atau ritual

Stephen P. Robbins mendefinisikan ritual sebagai deretan berulang dari kegiatan yang mengungkapkan dan memperkuat nilai-nilai utama organisasi itu, tujuan apakah yang paling penting, orangorang manakah yang penting dan mana yang dapat dikorbankan. Ritual merupakan tempat di mana perusahaan secara simbolis menghormati pahlawan-pahlawannya. Misalnya penghargaan kepada 
karyawan yang berhasil memajukan perusahaan yang dilaksanakan setiap tahun (Tika, 2005 : 17). Sedangkan menurut Kasali (1994 : 115) Ada 4 macam bentuk ritus atau ritual yang dapat dikembangkan:

1) Ritus penerimaan

Acara ini didesain untuk memberikan orientasi pada anggota baru, sebagai masa transisi bagi seseorang untuk memasuki nilainilai social baru dan status baru.

2) Ritus penguatan

Acara ini diselenggarakan untuk mengingatkan seseorang bahwa dia telah memasuki kedudukan yang agak senior dalam perusahaan. Tujuannya adalah untuk memperteguh identitas sosial dan meningkatkan status karyawan. Biasanya dilakukan dengan pemberian award tertentu.

3) Ritus pembaruan

Acara ini dilakukan dengan maksud meningkatkan kemampuan seseorang melalui suatu program pelatihan berjenjang yang sangat kompetitif dan berjangka waktu cukup lama. Pembaruan akan meningkatkan disiplin dan rasa telah melewati babak baru.

4) Ritus integrasi

Acara ini dilakukan dengan maksud untuk menciptakan iklim dan perasaan kebersamaan diantara karyawan dan menimbulkan komitmen terhadap organisasi.

5) Jaringan budaya

Jaringan budaya adalah jaringan informasi informal yang pada dasarnya merupakan saluran komunikasi primer. Fungsinya menyalurkan informasi dan memberi interpretasi terhadap informasi. Agar budaya organisasi dapat tersampaikan dan terinternalisasi dengan baik pada seluruh karyawan, maka perlu adanya komunikasi yang baik pula di dalam organisasi itu.

\section{Proses Internalisasi budaya}

Internalisasi memiliki hubungan yang erat dengan komunikasi. Dalam internalisasi budaya di dalam suatu organisasi, dibutuhkan suatu komunikasi yang baik agar pesan-pesan yang disampaikan dari tingkat teratas dapat diterima dengan baik oleh seluruh anggota organisasi. 
Komunikasi dapat mempermudah dalam melakukan internalisasi budaya organisasi, karena dengan adanya komunikasi yang optimal (dilakukan secara konsisten dan bisa dimengerti dengan jelas), maka karyawan akan memiliki kesadaran yang tinggi terhadap budaya yang ada di dalam organisasi. Sehingga jika karyawan menerapkan budaya organisasi tersebut dalam bekerja, maka kinerja karyawan dapat menjadi lebih baik. Kinerja organisasi mempengaruhi keberhasilan suatu organisasi dalam mencapai tujuannya. Kinerja seorang karyawan di dalam suatu organisasi bisa dipengaruhi oleh kecerdasan dan ketrampilan yang dimiliki, kondisi karyawan tersebut, kondisi organisasi tersebut, dan juga peraturan dan nilainilai (budaya) di dalam organisasi itu. Menurut Prawiro Suntoro (Tika, 2005 :121), kinerja adalah hasil kerja yang dapat dicapai seseorang atau sekelompok orang dalam suatu organisasi untuk mencapai tujuan organisasi tersebut dalam kurun waktu tertentu. Itulah sebabnya mengapa internalisasi budaya organisasi penting untuk dilaksanakan.

Proses merupakan pengaitan urutan tindakan/interaksi bila urutan tersebut berhubungan dengan penanganan, pengendalian, ataupun tanggapan terhadap suatu fenomena (Anselm Strauss \& Juliet Corbin, 2003:157). Proses budaya adalah proses terbentuknya budaya di dalam suatu organisasi. Proses ini terdiri dari sejumlah subproses yang saling terjalin, antara lain kontak budaya, penggalian budaya, seleksi budaya, pemantapan budaya, sosialisasi budaya, internalisasi budaya, control budaya, evaluasi budaya, pertahanan budaya, perubahan budaya, dan pewarisan budaya, yang terjadi dalam hubungan suatu organisasi dengan lingkungannya secara berkesinambungan (Ndraha, 1997:69).

Internalisasi budaya merupakan pengalihan nilai-nilai yang dialami dan dihayati individu sepanjang hidupnya sebagai anggota masyarakat (Haryono, 1996 : 68). Biasanya pengalihan nilai tersebut memberi kesan yang mendalam pada individu tersebut. Dalam bahasa Inggris, internalized to incorporate in oneself. Proses internalisasi adalah proses menanamkan dan menumbuhkembangkan suatu nilai atau budaya menjadi bagian diri orang yang bersangkutan. Penanaman dan penumbuhkembangan nilai tersebut dilakukan melalui berbagai metode pendidikan dan pengajaran (Ndraha, 1997:83).

Dengan kata lain, proses internalisasi adalah proses dimana seseorang menimbangnimbang, menerima, menghayati mampu mempraktekkan nilai dan perilaku baru dalam hidupnya. Proses internalisasi akan meliputi lima tahap yaitu awareness (pengetahuan/kesadaran), understanding (mengerti), assessment (penaksiran/penilaian), acceptance (penerimaan/dukungan), dan implementation (pelaksanaan).

Tahap awareness dan understanding lazim disebut proses ke dalam karena ada nilainilai yang dimasukkan ke dalam diri seseorang. Dalam proses ini karyawan diberi 
rangsangan-rangsangan dalam berbagai bentuk (diperkenalkan dengan budaya-budaya yang berlaku di dalam organisasi tersebut) agar mereka sadar dan mengerti akan nilai perilaku baru. Menyadari dan memahami nilai dan perilaku baru tidaklah cukup untuk mempraktekkannya. Karyawan harus menimbang-nimbang (assessing) nilai dan perilaku tersebut dan setelah itu baru dapat memutuskan menerima nilai tersebut atau menolaknya. Baru setelah dia dalam posisi menerima (acceptance) maka dia dapat menghayati sebagai perilaku baru dan mempraktekkannya/melaksanakan dalam keseharian (implementation). Internalisasi sering disebut proses keluar karena nilai-nilai yang sudah tertanam harus dapat dipraktekkan.

\section{Proses Internalisasi Budaya di Universitas Ahmad Dahlan Yogyakarta}

Dalam melakukan internalisais budaya organisasi yang ada di dalamnya, Universitas Ahmad Dahlan berpegang pada Sistem Perkaderan Muhamadiyah (SPM), hal ini tidak lain karena Universitas Ahmad Dahlan adalah Amal Usaha Muhammadiyah (AUM) sehingga setiap kebijakan yang berkaitan dengan ke-SDM-an, apa lagi jika menjadi budaya organisasi, tidak bisa terlepas dari yang namanya SPM.

SPM dirumuskan dalam forum tertinggi Muhammadiyah yang diikutim oleh seluruh majelis dari segala tingkatan kepemimpinan dalam Muhammadiyah (ranting hingga pusat) beserta seluruh organisasi otonom (ortom) dan diikutipula oleh seluruh pimpinan AUM. Sehingga kebijakan tersebut harus ditaati oleh seluruh warga Muhammadiyah termasuh disini adalah Universitas Ahmad Dahlan. Dan dalam SPM tersebut, disebutkan bahwa proses internalisasi budaya yang berlangsung dalam AUM semuanya terangkum dala sebuah acara yang bernama Baitul Arqam (BA).

Dalam BA terdapat materi-materi wajib dan materi-materi suplemen yag harus disampaikan pada para peserta BA. Materi-materi wajib diberikan sesuai dengan apa-apa yang disampaikan secara formal dalam SPM, sedangkan materi-materi suplemen diberikan sesuai dengan kebutuhan AUM, dalam hal ini adalah Universitas Ahmad Dahlan Yogyakarta.

Nah disinilah bidang SDM dan Humas Universitas Ahmad Dahlan menjalankan perannya supaya proses internalisasi budaya Universitas Ahmad Dahlan dapat terkolaborasikan dan terinternalisasikan dengan baik dalam diri seluruh SDM Universitas Ahmad Dahlan dari segala tingkatan. Supaya ada integrasi yang baik kelokalan Universitas Ahmad Dahlan Yogyakarta denganketentuan dari keputusan Muhammadiyah selaku pemilik dari Universitas Ahmad Dahlan

Dalam melakukan BA, Universitas Ahmad Dahlan tidak serta merta mengikutkan seluruh SDM nya dalam acara ini. Yang dilakukan pertama kali oleh Universitas Ahmad 
Dahlan adalah melakukan pemetaan terhadap seluruh SDM nya. Universitas Ahmad Dahlan memperhatikan sekiranya SDM mana saja yang perlu untuk mendapatkan bimbingan khusus dalam menerima dan mengamalkan budaya organisasi di Universitas Ahmad Dahlan Yogyakarta. Hal ini dilakukan melihat keefektivitasan acara, mengingat tidak semua SDM perlu pendampingan lebih.

Dalam melakukan BA, bidang SDM Universitas Ahmad Dahlan Yogyakarta melakukan kerjasama dengan Majelis Pendidikan Kader (MPK) Pimpinan Wilayah Muhammadiyah (PWM) Daerah Istimewa Yogyakarta (DIY). Hal ini dilakukan sekali lagi tidak terlepas dari status AUM yang ada dalam tubuh Universitas Ahmad Dahlan. MPK PWM DIY memiliki tangungjawab untuk memastikan bahwa budaya organsasi yang menjadi dasar Universitas Ahmad Dahlan tidak melenceng dari keyakinan dan cita-cita hidup Muhammadiyah.

Maka dalam prosesnya bidang SDM Universitas Ahmad Dahlan melakukan pendekatan-pendekatan yang bersifat kultural pada tiap SDM yang ada di Universitas Ahmad Dahlan (pendekatan-pendekatan yang bersifat struktural untuk melakukan monitoring dan evaluasi kinerja telah dilaksanakan oleh bidang personalia/Bidang SDM). Setelah memiliki catatan-catatan dari hasil observasi terhadap para SDM dan data dari bidang SDM terkait perkembangan pegawai baik medis mau pun non medis, Humas menghubungi MPK PWM DIY untuk lantas mencanangkan BA yang nantinya mampu meningkatkan kinerja dan internalisasi budaya organisasi dalam tubuh institusi Universitas Ahmad Dahlan.

Apa bila dijabarkan maka proses BA di Universitas Ahmad Dahlan Yogyakarta dapat digambarkan sebagaimana berikut:

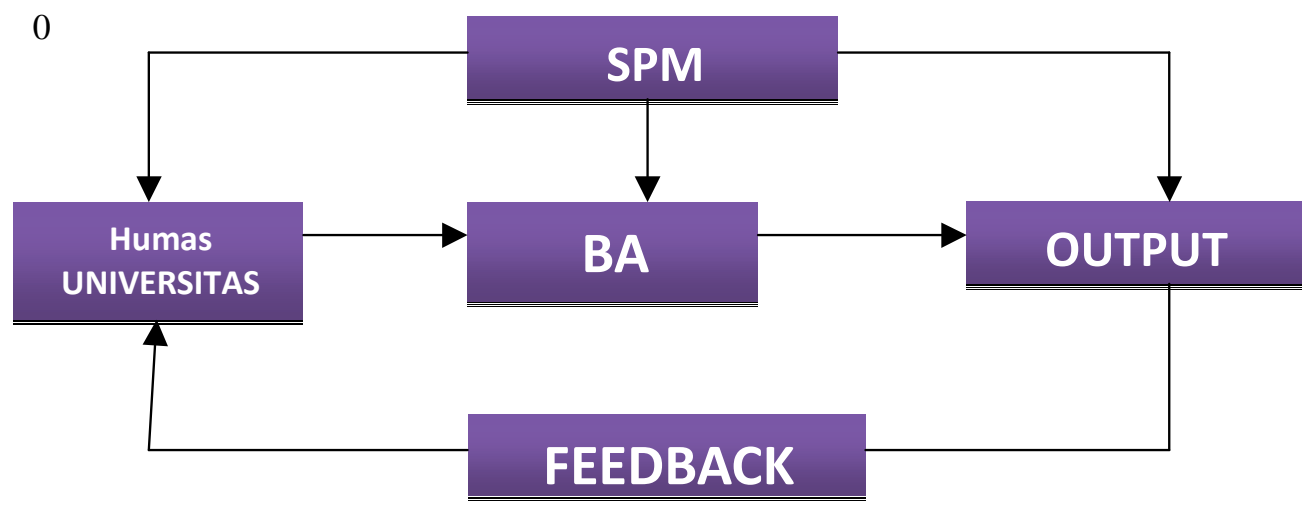

Dalam alur diatas dapat dijelaskan bagaimana bidang SDM Universitas Ahmad Dahlan menghubungi dan bekerjasama dengan MPK PWM DIY untuk melaksanakan BA, dan yang harus digasrisbawahi adalah dalam tiap kegiatan baik mulai dari perencanaan BA oleh Universitas Ahmad Dahlan dan MPK PWM DIY, hari kegiatan, dan out put dari BA 
harus selalu bepedoman pada SPM. Out put dari kegiatan tersebut akan terus dimonitoring kemajuannya dalam bermuhammadiyah dan menjalankan budaya organisasi dengan baik. Hingga jika telah tiba saatnya para SDM perlu di BA kan kembali.

\section{Proses BA Universitas Ahmad Dahlan Muhammadiyah Yogyakarta}

Dalam prosesnya BA memiliki dua metode ketika telah dilaksanakan, yaitu indoor dan outdoor. Kegiatan yang dilakukan dalam ruang (indoor) akan dilaksanakan ketika materi yang disampaikan membutuhkan kenyamanan dalam melakukan diskusi secara mendalam antara pemateri dan peserta atau pun antara peserta dengan sesama peserta. Sedangkan kegiatan outdoor dilaksanakan ketika materi yang bersangkutan memerlukan ruang lebih dalam melakukan gerakan fisik dalam pelaksanaannya.

Materi yang disampaikan dalam BA pun meliputi dua kategori, yaitu materi yang bersifat wajib dan materi suplemen. Materi wajib disampaikan padapara peserta karena itu merupakan inti dari budaya Universitas Ahmad Dahlan yang harus dimiliki oleh seluruh

SDM Universitas Ahmad Dahlan baik tenaga medis mau pun non medis, kemuhammadiyahan dan keislaman. Sedangkan materi suplemen adalah materi tambahan yang merupakan hal-hal sekunder yang harus dimiliki oleh AUM yang bersangkutan. Tergantung kearifan lokan yang dimiliki oleh masing-masing AUM baik dari budaya, geografis mau pun spesialisasi yang dimiliki oleh AUM yang bersangkutan.

Universitas Ahmad Dahlan Muhammadiyah Yogyakarta yang merupakan instansi pendidikan tinggi tentu memiliki budaya organisasi yang berbeda dari AUM yang merupakan instansi jurnalistik dan pendidikan menengah, juga meski sesama instansi pendidikan tinggi Universitas Ahmad Dahlan Yogyakarta pasti memiliki keraifan loka yang berbeda dengan Perguruan Tinggi Muhammadiyah Lainnya, disinilah materi suplemen itu bermain untuk melakukan internalisasi organisasi dalam tubuh Universitas Ahmad Dahlan Yogyakarta, ada penyesuaian berdasarkan tipe instansi dan letak geografis serta sosio-kultural masyarakatnya.

\section{Materi Keislaman}

Dalam materi keislaman para peserta diberi pemahaman sebagai berikut:

a. Agama, yakni Agama Islam yang dibawa oleh Nabi Muhammad S.A.W. ialah apa yang diturunkan Allah dalam Al-Quran dan yang disebut dalam Sunnah yang shahih, berupa perintah-perintah, larangan-larangan, dan petunjuk-petunjuk untuk kebaikan manusia di dunia dan akhirat (Kitab Masalah Lima, Al-Masail Al-Khams tentang al-Din). 
b. Muhammadiyah berkeyakinan bahwa Islam adalah Agama Allah yang diwahyukan kepada para Rasul-Nya sejak Nabi Adam, Nuh, Ibrahim, Musa, Isa, dan seterusnya sampai kepada Nabi penutup Muhammad S.A.W., sebagai hidayah dan rahmat Allah kepada umat manusia sepanjang masa, dan menjamin kesejahteraan hidup materiil dan spirituil, duniawi dan ukhrawi (Matan Keyakinan dan Cita-cita Hidup Muhammadiyah/MKCHM butir ke-2).

c. Muhammadiyah dalam mengamalkan Islam berdasarkan (a) Al-Quran: Kitab Allah yang diwahyukan kepada Nabi Muhammad S.A.W.; (b) Sunnah Rasul: penjelasan dan pelaksanaan ajaran-ajaran Al-Quran yang diberikan oleh Nabi Muhammad S.A.W.; dengan menggunakan akal pikiran sesuai dengan jiwa ajaran Islam (MKCH butir ke-3).

d. Muhammadiyah bekerja untuk terlaksananya ajaran-ajaran Islam yang meliputi bidangbidang: (a) 'Aqidah; Muhammadiyah bekerja untuk tegaknya aqidah Islam yang murni, bersih dari gejala-gejala kemusyrikan, bid'ah dan khurafat, tanpa mengabaikan prinsip toleransi menurut ajaran Islam; (b) Akhlaq; Muhammadiyah bekerja untuk tegaknya nilai-nilai akhlaq mulia dengan berpedoman kepada ajaran-ajaran Al-Quran dan Sunnah Rasul, tidak bersendi kepada nilainilai ciptaan manusia; (c) 'Ibadah; Muhammadiyah bekerja untuk tegaknya 'ibadah yang dituntunkan oleh Rasulullah S.A.W. tanpa tambahan dan perubahan dari manusia; (d) Mu'amalah dunyawiyat; Muhammadiyah bekerja untuk terlaksananya mu'amalah dunyawiyat (pengolahan dunia dan pembinaan masyarakat) dengan berdasarkan ajaran Agama serta menjadikan semua kegiatan dalam bidang ini sebagai 'ibadah kepada Allah S.W.T. (MKCH, butir ke-4).

e. Islam adalah agama untuk penyerahan diri semata-mata karena Allah, agama semua Nabi, agama yang sesuai dengan fi trah manusia, agama yang menjadi petunjuk bagi manusia, agama yang mengatur hubungan dengan Tuhan dan hubungan manusia dengan sesama, dan agama yang menjadi rahmat bagi semesta alam. Islam satu-satunya agama yang diridhai Allah dan agama yang sempurna. Dengan beragama Islam maka setiap muslim memiliki dasar/ landasan hidup tauhid kepada Allah, fungsi/peran dalam kehidupan berupa ibadah, menjalankan kekhalifahan, dan bertujuan untuk meraih ridha serta karunia Allah SWT. Islam yang mulia dan utama itu 
akan menjadi kenyataan dalam kehidupan di dunia apabila benar-benar diimani, dipahami, dihayati, dan diamalkan oleh seluruh pemeluknya (orang Islam, umat Islam) secara total atau kaffah dan penuh ketundukan atau penyerahan diri. Dengan pengamalan Islam yang sepenuh hati dan sungguh-sungguh itu, maka terbentuk manusia muslimin yang memiliki sifat-sifat utama: kepribadian muslim, kepribadian mukmin, kepribadian muhsin dalam arti berakhlak mulia, dan kepribadian muttaqin (Pedoman Hidup Islami Warga Muhammadiyah/PHIWM, bab Pandangan Islam Tentang Kehidupan).

f. Bahwa dasar muthlaq untuk berhukum dalam agama Islam adalah Al-Quran dan Al-Hadits. Bahwa di mana perlu dalam menghadapi soal-soal yang telah terjadi dan sangat dihajatkan untuk diamalkannya, mengenai hal-hal yang tak bersangkutan dengan 'ibadah mahdhah padahal untuk alasan atasnya tiada terdapat nash sharih dalam Al-Quran dan Sunnah shahihah, maka dipergunakanlah alasan dengan jalan ijtihad dan istimbath dari nash yang ada melalui persamaan 'illat, sebagaimana telah dilakukan oleh 'ulama salaf dan Khalaf (Kitab Masalah Lima, Al-Masail Al-Khams tentang Qiyas). Prinsip-prinsip pemahaman agama dalam Muhammadiyahtersistematisasi dalam Manhaj Tarjih, bukan pemahaman orang-perorang. Sedangkan pengembangan tajdid diperlukan untuk kemajuan hidup dalam satu kesatuan antara tarjih dan pemikiran Islam atau antara pemurnian dan dinamisasi sebagaimana prinsip pemahaman Islam dalam Muhammadiyah.

g. Muhammadiyah dalam memaknai tajdid mengandung dua pengertian, yakni pemurnian (purifikasi) dan pembaruan (dinamisasi) (Keputusan Munas Tarjih di Malang). Muhammadiyah adalah Gerakan Islam, dakwah amar ma'ruf nahi munkar dan tajdid, bersumber pada Al- Quran dan Sunnah (AD Muhammadiyah, 2005). Salah satu dari enam prioritas program Muhammadiyah periode 2005-2010 ialah pengembangan tajdid di bidang tarjih dan pemikiran Islam secara intensif dengan menguatkan kembali rumusan-rumusan teologis seperti tauhid sosial, serta gagasan operasional seperti dakwah jamaah, dengan tetap memperhatikan prinsip dasar organisasi dan nilai Islam yang hidup dan menggerakkan (Keputusan Muktamar ke-45 di Malang tahun 2005). Hal yang penting yang perlu 
menjadi pemahaman bersama bahwa paham Islam dalam Muhammadiyah bersifat komprehensif dan luas, sehingga tidak sempit dan parsial. Agama dalam pandangan atau paham Muhammadiyah tidaklah sepotong-sepotong, serpihan-serpihan, dan hanya hukum/fi kih belaka. Paham agama yang ditamankan bukan ajaran yang terbatas, tetapi luas dan mulsiaspek. Karena Muhammadiyah merupakan gerakan Islam, maka paham tentang Islam merupakan kewajiban atau keniscayaan yang fundamental, yang initinya pada memperdalam sekaligus memperluas paham Islam bagi seluruh warga Muhammadiyah, kemudian menyebarkan/mensosialisasikan dan mengamalkan dalam kehidupan umat serta masyarakat sehingga Islam yang didakwahkan Muhammadiyah membawa/ menjadi rahmatan lil-'alamin. Sedangkan dalam Baitul Arqam ada agenda-agenda penting yang turut menopang keberhasilan internalisasi budaya organisasi tersebut. Agenda itu adalah penyampaian visi misi Muhammadiyah dan prinsip Internalisasi sistem manajemen.

\section{Materi Kemuhammadiyahan}

Dalam materi keislaman para peserta akan mendapatkan doktrinasi mengenai Muhammadiyah. Disaat kita bekerja di Amal Usaha Muhammadiyah, maka sudah sewajarnya kita mempelajari dan memahami apa itu Muhammadiyah. Salah satu yang dipelajari dalam Baitul Arqam adalah Paham Agama dalam Muhammadiyah, yang menjelaskan prinsip prinsip ibadah yang benar. Muhammadiyah adalah gerakan Islam yang melaksanakan dakwah dan tajdid untuk terwujudnya masyarakat Islam yang sebenar-benarnya.

Sebagai gerakan dakwah, Muhammadiyah mengajak umat manusia untuk memeluk agama Islam (da'wah ila al-Khair), menyuruh pada yang ma'ruf (al-amr bi al-ma'ruf), dan mencegah dari yang munkar (al-nahy 'an al-munkar) \{QS. Ali Imran/3: 104\}, sehingga hidup manusia slamat, bahagia, dan sejahtera di dunia dan akhirat. Karena itu seluruh warga, pimpinan, hingga berbagai komponen yang terdapat dalam Muhammadiyah, termasuk amal usaha dan orang-orang yang berada di dalamnya, haruslah memahami Muhammadiyah serta mengaktualisasikannya dalam kehidupan nyata. Dalam memahami hakikat Muhammadiyah, karena Persyarikatan ini merupakan gerakan Islam sebagaimana disebutkan di atas, maka merupakan kewajiban bagi seluruh warga dan pimpinan serta segenap pengelola dan pelaksana di lingkungan struktur Persyarikatan 
termasuk di amal usahanya, untuk memahami Islam sebagaimana paham agama dalam Muhammadiyah.

Tuntutan seperti ini bukan bermazhab dan taklid, tetapi sebagai bentuk 'ittiba sekaligus keniscayaan menyetujui asas dan tujuan Muhammadiyah, sebagaimana lazimnya siapapun yang berada dalam rumah Muhammadiyah. Dan dalam beragama sebagaimana paham Muhammadiyah, haruslah benar dan lurus, sebagaimana Firman Allah SWT dalam Al-Quran, yang artinya: "Maka hadapkanlah wajahmu dengan lurus kepada agama Allah; (tetaplah atas) fitrah Allah yang telah menciptakan manusia menurut fitrah itu. Tidak ada peubahan pada fi trah Allah. (Itulah) agama yang lurus; tetapi kebanyakan manusia tidak mengetahui (QS. Al-Rum: 30)".

Internalisasi mengenai pemahaman agama Islam yang diberikan pada berbagai institusi Muhammadiyah terangkum dalam materi Al-Islam dan Kemuhammadiyahan yang merupakan sistematisasi dan metodologis interaksi formal usaha pengarahan perkembangan manusia sebagai 'abid dan khalifah yang terikat dalam sistematika gerakan Islam dan dakwah, menekankan pengembangan ilmu umum dengan peranan sekolah sebagaimana yang berkembang sesuai dengan tuntutan kebutuhan masyarakat.

\section{Materi Suplemen : Kepemimpinan}

Pada materi suplemen ini menitikberatkan pada Pengembangan kemampuan kreatifitas dan akhlak dalam pembekalan karyawan dalam kehidupannya dijadikan program prioritas dalam budaya Muhammadiyah. Setiap karyawan dalam AUM, dalam hal ini adalah Universitas Ahmad Dahlan Yogyakarta bukan hanya memikirkan dirinya sendiri untuk bekerja menafkahi keluarga, nmaun harus hadir sebagai pionir di tengah masyarakat.

Hal ini sejalan dengan jiwa pembaharuan yang dicita-citakan yaitu mengembangkan nalar, menolak bid'ah, khurafat dan taqlid. Universitas Ahmad Dahlan menanamkan pada para SDM nya utamanya adalah ijtihad. Hal ini menjadikan produk didikan Muhammadiyah menampilkan wawasan yang luas, tidak picik, tidak tradisional, toleransi tetapi bukan sinkretis lebih jauh lagi umumnya menjadi manusia berpandangan bebas dan tidak bersedia didikte.

\section{Kesimpulan}


Pertama, dalam pemilihan metode yang akan digunakan untuk melakukan internalisasi budaya organisasi terhadap para karyawan yang menggerakan organisasi, Universitas Ahmad Dahlan Yogyakarta harus mempercayakannya metodenya terhadap konsep yang telah disiapkan dan diformulasikan oleh Pimpinan Pusat Muhammadiyah, mengingat sebagai AUM (Amal Usaha Muhammadiyah) yang memiliki kekhasan tersendiri dan tidak bisa dibandingkan dengan institusi serupa yang ada pada umumnya

Kedua, Baitul Arqam yang menjadi metode khusus yang telah ditetapkan oleh Pimpinan Pusat Muhammadiyah sebagai sarana untuk menginternalisasikan budaya organisasi yang sesuai dengan gaya dan ajaran KH Ahmad Dahlan harus dijaga kesakralan dan subtansi isinya.

Ketiga, tidaklah cukup hanya dengan menggunakan sistem perkaderan baku saja, karena dalam pelaksanaannya Baitul Arqam harus senantiasa diisi dengan improfisasi supaya tidak mendatangkan rasa jenuh pada diri karyawan yang diikutkan dalam program tersebut. 


\section{Daftar Pustaka}

Effendy, Onong Uchjana. 1993. Ilmu, Teori dan Filsafat Komunikasi. Bandung: PT. Citra Aditya Bakti.

Effendy, Onong Uchjana. 2008. Dinamika Komunikasi. Bandung: Rosda Karya.

Kreitner, Roberto \& Kinicki Angelo. 2003. Organizational Behavior. Singapore: Mc Graw Hill.

Kristanto, Joseph. 2006. Belakar Berdasar Regulasi Dini Ditinjau Dari Kesadaran Diri dan Kecerdasan Emosi Pada Mahasiswa Seminari Tinggi. Thesis. Yogyakarta: UGM

Liliweri, Alo. 1997. Sosiologi Organisasi. Bandung: PT. Citra Aditya Bakti.

Liliweri, Alo. 2004. Wacana Komunikasi Organisasi. Bandung: CV. Mandar maju.

Littlejhon, Steven W. 2011. Theories of Human Communications. Jakarta: Salemba Humanika.

Matan Keyakinan Cita-Cita Hidup Muhammadiyah

Morissan. 2009. Teori Komunikasi Organisasi. Jakarta; Global Indonesia.

Moleong, Lexx J. 2009. Metode Penelitian Kualitatif. Bandung: remaja Rosda Karya.

Muhammad, Arni. 2002. Komunikasi Organisasi. Jakarta: Bumi Aksara.

Ndraha. Talizuduhu. 1997. Budaya Organisasi. Jakarta: PT Rineka Cipta.

O’Dea, Thomas F. 1996. Sosiologi Agama. Jakarta: Raja Grafindo Persada.

Robin, Stephen, P. 2003. Organizational Behaviour, Tenth Edition. New Jersey Prectice Hall.

Wayne, Pace R \& Don, F. Faules. 2010. Komunikasi Organisasi: Strategi Meningkatkan Kinerja Perusahaan. Terjemahan: Deddy Mulyana. Bandung : remaja Rosda Karya. 